\title{
Eyelid Disorder
}

National Cancer Institute

\section{Source}

National Cancer Institute. Eyelid Disorder. NCI Thesaurus. Code C26768.

Any disease affecting the eyelid. 